\title{
Persepsi Mahasiswa terhadap Pembelajaran Mata Kuliah Umum Pendidikan Kewarganegaraan sebagai Sarana Pendidikan Politik
}

\author{
Guspalin Tomi Saputra, Al Rafni \\ Program Studi Pendidikan Pancasila dan Kewarganegaraan \\ Universitas Negeri Padang \\ E-mail: guspalintomi97@gmail.com
}

\section{ABSTRAK}

Penelitian ini bertujuan untuk mengidentifikasikan persepsi mahasiswa terhadap pembelajaran Pendidikan Kewarganegaraan atau PKn sebagai sarana pendidikan politik. Penelitian ini menggunakan metodedeskriptif kuantitatif dengan sampel penelitian adalah mahasiswa yang sudah mengambil mata kuliah umum Pendidikan Kewarganegaraan. Lokasi penelitian berada di Fakultas Ilmu Sosial Universitas Negeri Padang. Pengambilan sampel ini menggunakan teknik quota sampling dengan rumus Slovin yaitu pengambilan sampel dari anggota populasi dengan menggunakan acak tanpa memperhatikan strata. Sehingga memperoleh sampel sebanyak 50 orang. Instrumen penelitian ini berupa angket. Analisis data menggunakan rumus persentase. Hasil penelitian ini menunjukkan persepsi mahasiswa terhadap pembelajaran mata kuliah umum PKn dilihat dari konten, media, strategi pembelajaran dan evaluasi pembelajaran mata kuliah pendidikan kewarganegaraan sebagai pendidikan politik. Temuan penelitian menunjukan persepsi mahasiswa terhadap konteks pembelajaran PKn berada pada kriteria baik dengan memperoleh rata-rata persentasesangat setuju/seringyaitu 66\%. Persepsi mahasiswa terhadap strategi pembelajaran PKn berada pada kriteria baik dengan mempoleh rata-rata persentasesetuju/jarang dan sangat setuju/sering sebesar $84 \%$. Persepsi mahasiswa terhadap media pembelajaran PKn berada pada kriteria baik dengan mempoleh rata-rata persentasesebesar 73,33\%. Persepsi mahasiswa terhadap evaluasi pembelajaran PKn memperolehrata-rata persentase sebesar $96 \%$.

Kata Kunci: Pendidikan Politik, mahasiswa, Pendidikan Kewarganegaraan

\section{ABSTRACT}

This study aims to identify students' perceptions of Citizenship Education or Civics Education learning as a means of political education. This study uses quantitative descriptive methods with a sample of research are students who have taken general courses in Citizenship Education. The research location is in the Faculty of Social Sciences, Padang State University. This sampling uses the Quota Sampling technique with the Slovin formula which is sampling from members of the population using random without regard to strata. So as to get a sample of 50 people. The research instrument was in the form of a questionnaire. Data analysis used the percentage formula. The results of this study showed students' perceptions 
of the learning of general Civics courses viewed from the content, media, learning strategies and evaluation of civics education courses as political education. The research findings show that students' perceptions of the context of Civics learning are in good criteria by obtaining an average percentage of very agree / often namely 66\%. Student perceptions of Civics learning strategies are in good criteria by obtaining an average percentage of agreed / rare and strongly agree / often by $84 \%$. Students' perceptions of Civics learning media are in good criteria by obtaining an average of $73.33 \%$. Students' perceptions of the evaluation of Civics Learning get an average percentage of $96 \%$.

Keywords : political education, students, civics education

This work is licensed under the Creative Commons Attribution-ShareAlike 4.0 International License. (C)2019 by author.

\section{PENDAHULUAN}

Pendidikan Kewarganegaraan dikatakan sebagai pendidikan politik karena mata kuliah PKn ini sebagai sarana pembangun bangasa dan watak bangsa, serta berperan sebagai salah satu syarat untuk memciptakan pemerintahan yang demokratis. Selain itu PKn sebagai sistem persistence dan system maintenance bagi sistem politik atau kemampuan bertahan dan terpeliharanya sistem politik secara terus-menerus. Pendidikan politik adalah proses pembelajaran dan pemahaman tentang hak, kewajiban, dan tanggung jawab setiap warga negara dalam kehidupan berbangsa dan bernegara. Kartaprawira (2004) mengartikan politik sebagai upaya untuk meningkatkan pengetahuan politik rakyat dan agar mereka dapat berpartisipasi secara maksimal dalam sistem politiknya.

Pendidikan politik sangat penting bagi masyarakat terutama kepada mahasiswa tahun pertama dan kedua. Dimana mereka merupakan pemilih pemula agar mereka tidak buta terhadap politik, mengetahui hak, kewajiban, dan tanggungjawabnya sebagai warga negara. Disebabkan oleh permasalahan-permasalahan politik sangat kompleks dan dinamis maka pendidikan politik bagi generasi muda sejak dini harus dimantapkan. Apalagi mereka sebagai pemilih pemula sangatlah vital dalam mendukung perbaikan sistem politik Indonesia.

Pendidikan politik betujuan untuk menanamkan pemahaman dan bermacam aspek yang muncul dari setiap permasalahan yang berkaitan dengan dunia politik (Aina: 2015). Pendidikan politik bertujuan untuk membentuk dan menumbuhkan kepribadian politik, kesadaran politik dan membentuk kemampuan individu dalam berpartisipasi politik. Pendidikan politik ini sangatlah penting terutama bagi mahasiswa yang tidak pernah mempelajari mata kuliah pendidikan politik di jurusan mereka. Berbeda dengan jurusan Ilmu Sosial Politik Universitas Negeri Padang yang mempelajari hal tersebut sebagai mata kuliah wajib jurusan.

Melihat hal tersebut tidak dapat dipungkiri bahwa masih banyak dari kalangan mahasiswa yang memiliki pengetahuan minim terhadap perannya sebagai pelaku politik. Dengan adanya kendala dalam hal 
materi pendidikan politik yang terlalu sedikit dimuat dalam pembelajaran mata kuliah umum PKn yang seharusnya menjadi sarana yang di harapkan dapat memperbaiki ketidaktahuan para mahasiswa dalam dunia politik yang dilaksanakan dalam masyarakat.

\section{METODE PENELITIAN}

Penelitian ini menggunakan metode penelitian deskriptif kuantitatif. Penelitian ini bermaksud untuk memahami secara utuh pendidikan politik yang dimiliki oleh mahasiswa Universitas Negeri Padang. Terkadang mahasiswa kurang memahami tentang pendidikan politik dan kurang tersampaikannya peran mata kuliah umum PKn sebagai sarana Pendidikan Politik. Informan dalam penelitian iniadalah mahasiswa yang sudah mengambil Mata Kuliah Umum PKn dengan Populasi mahasiswa Fakultas Ilmu Sosial yang berjumlah 100 orang. Pengambilan sampel pada penelitian ini menggunakan teknik random sampling dengan rumus Slovin yaitu pengambilan sampel dari anggota populasi dengan menggunakan acak tanpa memperhatikan strata (Sugiyono: 2012). Sehingga memperoleh sampel sebanyak 50 orang. Instrumen penelitian ini berupa angket. Kemudian analisis data menggunakan rumus persentase.

Teknik pengumpulan data yang digunakan meliputi angket, wawancara. Teknik analisis data menggunakan metode skala likert. Instrumen/alat penelitian yang dipakai adalah kuisioner/angket. Penyusunan angket dilakukan dengan langkah pembuatan kisi-kisi berdasarkan indikator variabel. Untuk mengukurnya peneliti menggunakan cara dengan memakai kuisioner tentang pilihan yang disusun seperti model likert. Skala Likert yang digunakan untuk mengukur pendapat dan persepsi seseorang atau kelompok orang tentang fenomena sosial dimana telah ditetapkan secara spesifik oleh penulis. Jawaban dari pertanyaan dalam penelitian ini disajikan dalam bentuk Skala Likert dengan empat kategori jawaban, yaitu ungkapan Sangat Setuju (SS)/Sering (S), Setuju (S)/Jarang (J), Tidak Setuju (TS)/Pernah (P), dan Sangat Tidak (STS)/Tidak Pernah (TP). Sugiono (2012).

\section{HASIL DAN PEMBAHASAN}

\section{Persepsi Mahasiswa terhadap konten Pembelajaran PKn}

Berdasarkan jawaban responden terhadap pembelajaran PKn yang berisi materi pendidikan politik tentang kesadaran politik memperoleh frekuensi pernah dan tidak pernah berjumlah 9 orang dengan jumlah persentase 18\%, frekuensi jarang dan sering berjumlah 41 orang dengan jumlah persentase $82 \%$. Berdasarkan hasil responden terhadap terhadap pembelajaran PKn yang berisi materi pendidikan politik tentang demokrasi memperoleh frekuensi sangat tidak setuju dan tidak setuju berjumlah 8 orang dengan persentase $16 \%$, frekuensi setuju dan sangat setuju berjumlah 42 orang dengan jumlah persentase $84 \%$.

Selanjutnya berdasarkan hasil responden terhadap pembelajaran PKn yang berisi materi pendidikan politik tentang peran partai politik memperoleh frekuensi pernah dan tidak pernah berjumlah 5 orang dengan jumlah persentase 10\%, 
frekuensi jarang dan sering berjumlah 45 orang dengan jumlah persentase $90 \%$. Selanjutnya berdasarkan hasil responden terhadap pembelajaran PKn yang berisi materi pendidikan politik tentang budaya politik memperoleh frekuensi pernah dan tidak pernah berjumlah 4 orang dengan jumlah persentase $8 \%$, frekuensi jarang dan sering berjumlah 46 orang dengan persentase $92 \%$.

Berdasarkan hasil responden terhadap pembelajaran $\mathrm{PKn}$ yang berisi materi pendidikan politik tentang pemberdayaan masyarakat dalam bidang politik memperoleh frekuensi pernah dan tidak pernah berjumlah 33 orang dengan jumlah persentase $66 \%$, frekuensi jarang dan sering berjumlah 17 orang dengan jumlah persentase $34 \%$.Berdasarkan hasil responden terhadap pembelajaran PKn yang berisi materi pendidikan politik tentang meningkatkan kesadaran masyarakat dalam politik memperoleh frekuensi pernah dan tidak pernah berjumlah 27 orang dengan jumlah persentase $54 \%$, frekuensi jarang dan sering berjumlah 23 orang dengan jumlah persentase $46 \%$. Selanjutnya berdasarkan hasil responden terhadap terhadap pembelajaran pendidikan kewarganegaraan yang berisi materi pendidikan politik tentang asas keterpaduan yang meningkatkan kesadaran masyarakat memperoleh frekuensi sangat tidak setuju dan tidak setuju berjumlah 33 orang dengan persentase $66 \%$, frekuensi setuju dan sangat setuju berjumlah 17 orang dengan jumlah persentase $34 \%$.

Sesuai dengan teori bahwa politik dapat diartikan sebagai usaha dan sistematis untuk membentuk
Volume 1 No. 42018

individu agar mampu menjadi partisipan yang bertanggungjawab secara etis dalam mencapai tujuantujuan politik bangsa dan meningkatkan kesadaran politik masyarakat serta melestarikan budaya politik bangsa. Dengan demikian mereka benar-benar memahami dan menghayati nilai-nilai yang terkandung dalam sistem politik yang ideal bagi suatu bangsa.

Hasil dari penghayatan tersebut akan melahirkan sikap dan pola tingkah laku politik baru yang mendukung sistem politik ideal tersebut, dan bersamaan dengan itu lahir pula kebudayaan politik baru yang lebih demokratis dalam kehidupan berbangsa dan bernegara (Rafni: 2014). Berkaitan degan persepsi mahasiswa terhadap media pembelajaran PKn dari tujuh sub indikator dapat dikatakan baik dengan memperoleh rata-rata persentase Sangat Setuju/Sering dan Setuju/Jarang sebesar $66 \%$.

\section{Persepsi Mahasiswa terhadap Strategi Pembelajaran PKn}

Berdasarkan hasil responden terhadap strategi pembelajaran PKn dengan strategi yang bersifat dialog kritis memperoleh frekuensi pernah dan tidak pernah berjumlah 7 orang dengan jumlah persentase $14 \%$, frekuensi jarang dan sering berjumlah 43 orang dengan jumlah persentase $86 \%$. Kemudian berdasarkan hasil responden terhadap strategi pembelajaran $\mathrm{PKn}$ dengan strategi yang lebih bersifat pengalaman langsung memperoleh frekuensi pernah dan tidak pernah berjumlah 8 orang dengan jumlah persentase $16 \%$, frekuensi jarang dan sering berjumlah 42 orang dengan jumlah persentase 
84\%.Berdasarkan hasil responden terhadap strategi pembelajaran PKn dengan strategi pembelajaran yang lebih bersifat kolaboratif memperoleh frekuensi pernah dan tidak pernah berjumlah 9 orang dengan jumlah persentase $18 \%$, frekuensi jarang dan sering berjumlah 41 orang dengan jumlah persentase $82 \%$.

Sesuai dengan teori Murdiono (2012) strategi yang perlu dikembangkan dalam pembelajaran PKn adalah strategi pembelajaran yang lebih bersifat dialog kritis, pengalaman langsung, kolaboratif, kooperatif, dan pembelajaran aktif. Strategi pembelajaran ini menekankan pada tiga ranah pembelajaran yaitu kognitif, afektif, dan psikomotorik. Berkaitan dengan persepsi mahasiswa terhadap strategi pembelajaran pendidikan kewarganegaraan dari tiga sub indikator dapat dikatakan baik dengan memperoleh rata-rata persentase Sangat Setuju/Sering dan Setuju/Jarang sebesar $84 \%$.

\section{Persepsi Mahasiswa terhadap Media Pembelajaran PKn}

Berdasarkan hasil responden terhadap media pembelajaran PKn dengan pembelajaran yang mampu membuat mahasiswa berimajinasi secara luasmemperoleh frekuensi pernah dan tidak pernah berjumlah 14 orang dengan jumlah persentase $28 \%$, frekuensi jarang dan sering berjumlah 36 orang dengan jumlah persentase $72 \%$.Berdasarkan hasil responden terhadap pembelajaran PKn dengan media pembelajaran tentang peristiwa yang terjadi dimasyarakat memperolehfrekuensi pernah dan tidak pernah berjumlah 10 orang dengan jumlah persentase $20 \%$, frekuensi jarang dan sering berjumlah
40 orang dengan jumlah persentase $80 \%$.Berdasarkan hasil responden terhadap media pembelajaran $\mathrm{PKn}$ dengan pembelajarantentang kasuskasus dinegara lain memperoleh frekuensi pernah dan tidak pernah berjumlah 16 orang dengan jumlah persentase $32 \%$, frekuensi jarang dan sering berjumlah 34 orang dengan jumlah persentase $68 \%$.

Sesuai dengan teori media yang merupakan segala sesuatu yang dapat digunakan untuk menyalurkan pesan dari pengirim ke penerima sehingga dapat merangsang pikiran, perasaan, perhatian, dan minat serta perhatian peserta didik sedemikian rupa sehingga proses belajar terjadi. Secara sederhana, untuk menyampaikan sesuatu hal atau informasi kepada orang lain, terlebih apabila yang akan menerima informasi tersebut dalam jumlah yang besar, dalam pertimbangan efektifitas dan efisiensi diperlukan perantara atau alat bantu untuk menyampaikan informasi tersebut agar informasi yang dimaksud dapat tersampaikan dengan baik (Soyomukti: 2008). Berkaitan dengan persepsi mahasiswa terhadap media pembelajaran PKn dari tiga sub indikatordapat dikatakan baik dengan memperoleh rata-rata persentase sangat setuju/sering dan setuju/jarang sebesar 73,33\%.

\section{Persepsi Mahasiswa terhadap Evaluasi Pembelajaran PKn}

Berdasarkan hasil responden terhadap evaluasi pembelajaran PKn menggunakan makalah memperoleh frekuensi pernah dan tidak pernah berjumlah 5 orang dengan jumlah persentase $10 \%$, frekuensi jarang dan sering berjumlah 45 orang dengan jumlah persentase $90 \%$. Berdasarkan 
hasil responden terhadap evaluasi pembelajaran PKn dengan evaluasi dengan fortofolio memperoleh frekuensi pernah dan tidak pernah berjumlah 2 orang dengan jumlah persentase $4 \%$, frekuensi jarang dan sering berjumlah 48 orang dengan jumlah persentase 96\%. Kemudian berdasarkan hasil responden terhadap evaluasi pembelajaran pendidikan kewarganegaraan dengan evaluasi dengan unjuk kerja memperoleh frekuensi pernah dan tidak pernah berjumlah 3 orang dengan jumlah persentase $6 \%$, frekuensi jarang dan sering berjumlah 47 orang dengan jumlah persentase $94 \%$.

Sesuai dengan teori evaluasi yang merupakan penilaian terhadap data-data yang terkumpulkan. Secara garis besar, pengertian evaluasi dalam pendidikan adalah pemberian nilai terhadap kualitas sesuatu (Arikunto, Suharsimi. 2015). Selain itu, evaluasi juga dipandang sebagai proses merencanakan, memperoleh dan menyediakan informasi yang sangatsangat diperlukan. Sehingga membentuk suatu proses evaluasi yang sistematis, menentukan atau membuat keputusan sejauh mana tujuan-tujuan pengajaran telah dicapai oleh mahasiswa. Berkaitan degan persepsi mahasiswa terhadap evaluasi pembelajaran $\mathrm{PKn}$ dari tiga sub indikator dapat dikatakan baik dengan memperoleh rata-rata persentase sangat setuju/sering dan setuju/jarang sebesar $96 \%$.

\section{KESIMPULAN}

Persepsi mahasiswa terhadap konteks pembelajaran PKn mempoleh rata-rata persentase yaitu $66 \%$. Persepsi mahasiswa terhadap strategi pembelajaran $\mathrm{PKn}$ memperoleh persentase sebesar $84 \%$. Persepsi mahasiswa terhadap media pembelajaran PKn memperoleh ratarata persentase sebesar 73,33\%. Persepsi mahasiswa terhadap evaluasi pembelajaran PKn memperoleh ratarata persentase sebesar 96\%. Dari seluruh hasil pengukuran tersebut maka terlihat bahwa persepsi mahasiswa terhadap pembelajaran PKn menunjukkan hasil yang positif dimana terlihat dari raihan persentase yang diatas $60 \%$.

\section{DAFTAR PUSTAKA}

Arikunto, Suharsimi. 2015. DasarDasar Evaluasi Pendidikan. Jakarta: Bumi Aksara.

Aina.2015. Pendidikan Politik bagi

Generasi Muda melalui Partai Politik. ISSN2089-3590, EISSN 2303-2472 Vol.5 No.1 2015.

Kartaprawira (2004). Aspek-aspek Pendidikan Politik dalam Kehidupan demokrasi untuk Mewujudkan Kecakapan Warga Negara yang Smart and Good Citizenship. Seminar Nasional Hukum Universitas Negeri Semarang. Volume.4 No. 3 2018, 1205-1228.

Murdiono (2012). Strategi Pembelajaran Berorientasi standar pendidikan. Bandung: Alfabeta

Rafni, A. (2012). Suryanef, 2 Al Rafni, 571-576.

Soyomukti: 2008. Pengembangan Media dan sumber Pembelajaran. Bandung: CV. Alfabeta

Sugiyono. 2012. Metode penelitian Kuantitatif Kualitatif dan R\&D. Bandung: ALFABETA 